\title{
A review of factors associated with the utilization of healthcare services and strategies for improving postpartum care in Africa
}

\author{
Danielle Yugbare Belemsaga (1), Seni Kouanda $(1,3)$, \\ Anne Goujon (2), Joel A. Kiendrebeogo (4), Els Duysburgh (5), \\ Olivier Degomme (5), Marleen Temmerman (6)
}

(I) Département biomédical et santé publique, Institut de Recherche en Sciences de la Santé, Burkina Faso

(2) Wittgenstein Centre for Demography and Global Human Capital, Austria

(3) Institut Africain de Santé Publique, Burkina Faso

(4) Centre Muraz, Burkina Faso

(5) International Centre for Reproductive Health, Belgium

(6) Department of Reproductive Health and Research, Switzerland

\begin{abstract}
Reducing maternal mortality continues to be a major challenge for African countries. We conducted a literature review to identify the factors associated with the utilization of maternal and child healthcare services during the postpartum period and the strategies for strengthening postpartum healthcare in Africa. We carried out an electronic search in several databases of texts published between 1995 and 2012 related to maternal and child health. Seventy-five publications fitted the eligibility criteria. Our analysis shows that to a large extent the socio-economic context was dominant among the factors associated with the quality and utilization of postpartum services. The best interventions were those on immediate postpartum maternal care combining several intervention packages such as community mobilization and provision of services, community outreach services and health training. The integration within health facilities of mother and child clinics was shown to contribute significantly to improving the frequency of mothers' postpartum visits.

Key words: postpartum care, postnatal care, maternal and child health, health interventions, health strategies, sub-Saharan Africa
\end{abstract}

\section{Introduction}

Despite a substantial decline in maternal mortality since 2003, this issue remains a major challenge for developing countries, especially in sub-Saharan Africa (Kassebaum et al., 2014). In western sub-Saharan Africa, the maternal mortality ratio (MMR) increased from 480 (95\% CI, 4I9-544) maternal deaths per Ioo,000 live births in 1990 
to 563 ( $95 \%$ CI, $489-639$ ) in 2003 , subsequently decreasing to 468 ( $95 \%$ CI, $385-564$ ) in 2013 (Kassebaum et al., 2014). Of the worldwide maternal deaths occurring in 2013, onequarter took place in the intrapartum and immediately postpartum periods $(28 \%)$, onethird 24 hours to 42 days after delivery ( $36 \%$ ), and ${ }_{2} \%$ between 43 days and one year after delivery (Kassebaum et al., 20I4). Three-quarters of the total neonatal deaths occurred in the first week of life (74\%) and about $40 \%$ in the first 24 hours of life (World Health Organisation, 2013). In this context, a continuum of care is essential for the survival of mother and child. This care includes the time from pre-pregnancy to the first year after delivery and the environment including the home, the community and health facilities (The Partnership for Maternal Newborn \& Child Health, 20II).

The goal of this systematic literature review is to identify (i) the factors associated with the utilization of mother and child health services during the postpartum period and (ii) the strategies recommended and/or implemented for the improvement of postpartum services. The overall objective is to help identify the relevant strategies for strengthening postpartum care in Africa.

\section{Methodology}

Study eligibility criteria

To be eligible for inclusion in the literature review, the primary topic of the study had to be mother and child health during the postpartum period in sub-Saharan Africa. In addition, the publication should - entirely or partially - address service utilization and delivery during the period together with associated factors and strategies used to improve them.

The postpartum period is the period that begins immediately after delivery of the placenta and lasts up to one year after birth (ICD-Io Version 2010, 2010). Postpartum care for both mother and child is defined as: (i) prevention, early detection and treatment of complications and diseases and (ii) provision of advice and services on breastfeeding, birth spacing, immunization and maternal nutrition. The main components of postpartum care vary in accordance with the postpartum stage, corresponding to a timetable of visits that has been summarized in the formula of " 6 hours, 6 days, 6 weeks and 6 months" (WHO, I998).

\section{Methods to identify applicable studies}

The time frame includes all publications released between I995 (5 years before the inception of the Millennium Development Goals) and 2012 (if the research was conducted until June 2012). We proceeded as follows:

(I) electronic searches in the following databases: SCIENCE DIRECT, AJOL, BIOMED CENTRAL, PUBMED and GOOGLE SCHOLAR;

(2) electronic searches on websites providing documentation resources on maternal and child health, i.e. World Health Organization (WHO), United Nations Children's Fund (UNICEF), UNFPA, Partnership for Maternal, Newborn \& Child Health (PM$\mathrm{NCH}$ ), United States Agency for International Development (USAID), World Bank, 
and the Demographic and Health Surveys (DHS) Program;

(3) consultation of the bibliography of the studies identified in Stage two. The electronic databases were searched using the following keywords: postpartum, postpartum period, postpartum care, postnatal, postnatal period, postnatal care, maternal and neonatal health, maternal and child health, Africa, sub-Saharan Africa, determinants, factors associated with strategies and combinations of words as shown in Figure I.
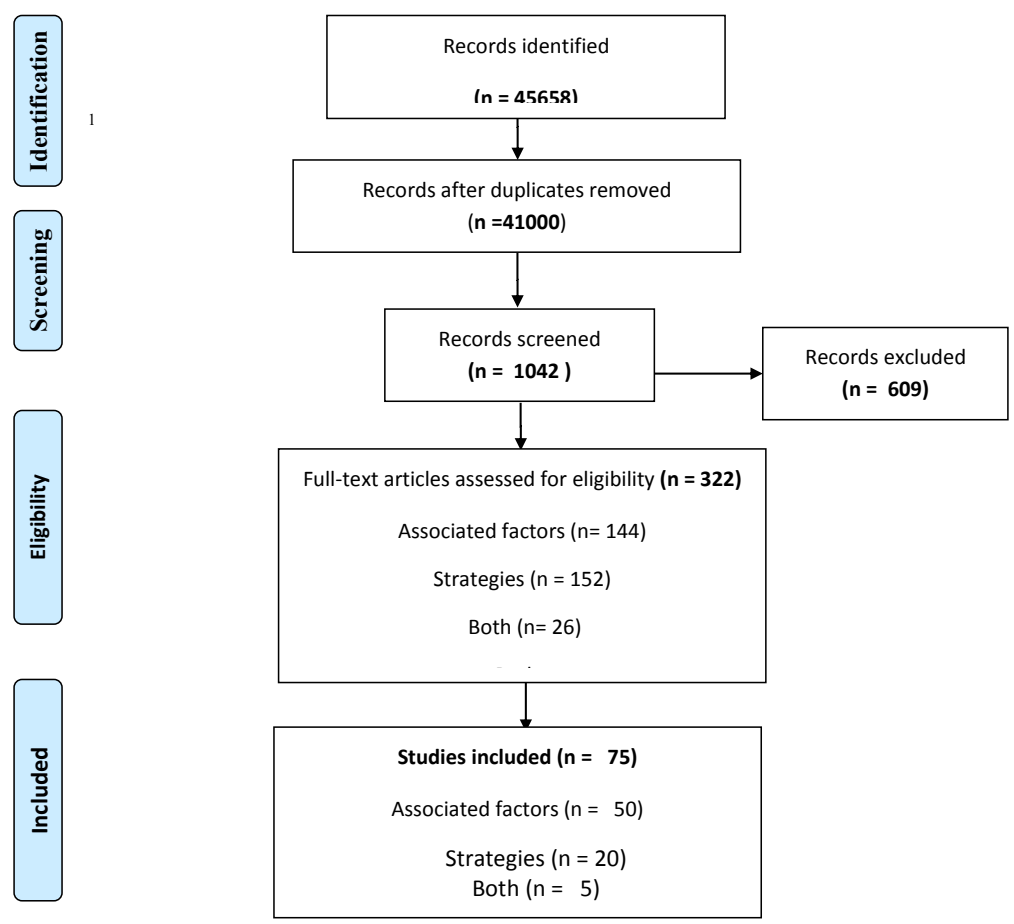

Figure 1 : Literature review flow chart following the PRISMA methodology (Moher D. et al., 2009)

${ }^{1}$ Using the following combination:

- For attendance at health centers: home birth, institutional birth, health services frequentation, health services utilization, non-institutional birth, access to health care.

- For qualified care for mother and newborn: skilled providers, trained providers, skilled birth attendance, traditional birth waiting, newborn care, newborn illness management.

- For contraception: birth spacing, birth control, family planning, contraception, contraceptive methods.

- For exclusive breast-feeding: breastfeeding, exclusive breastfeeding, breastfeeding promotion, child feeding, newborn feeding, infant feeding.

- For prevention of mother-to-child transmission of HIV (PTME): mother-to-child transmission of HIV, prevention of mother-to-child transmission, PMTCT, mother-to-child transmission, postnatal transmission, HAART, HIV infection. ${ }^{1}$

- For vaccination: expanded program of immunization EPI, childhood vaccination, childhood immunization, newborn vaccination, newborn immunization, immunization programs.

For specific care aiming at reducing maternal and/or neonatal morbidity and mortality: danger signs, severe obstetric complications, near-miss, adverse maternal outcomes, maternal morbidity and mortality, newborn morbidity 
The selection was performed in two steps. In the first step, we gathered all studies complying with the eligibility criteria by reading their titles and abstracts. In a second step, two researchers independently read all studies to refine the selection using a data extraction sheet.

Out of the eligible publications on associated factors (I44), on strategies (I52) and on both (26), we selected 75 publications as shown in Figure I.

Table I shows the distribution of countries and sub-themes studied.

\begin{tabular}{|c|c|c|c|c|}
\hline & \multicolumn{4}{|c|}{ Factors } \\
\hline Countries & $\begin{array}{l}\text { Utilization and skilled } \\
\text { attendance of health } \\
\text { services for mother and } \\
\text { newborn }\end{array}$ & Contraception & Breastfeeding and PMTCT & Immunization \\
\hline South Africa & & & 1 (Sprague et al., 2011) & \\
\hline Botswana & & & 1 (Shapiro et al., 2007) & \\
\hline Burkina Faso & $\begin{array}{l}2 \text { (Brazier et al., 2009; } \\
\text { Newlands et al., 2008) }\end{array}$ & $\begin{array}{l}1 \text { (Ganaba R.; Marshall } \\
\text { T.; Sombié I.; Baggaley } \\
\text { R.F.; Ouédraogo T.W. and } \\
\text { Filippi V., 2010) }\end{array}$ & 1 (Hofmann et al., 2009) & $\begin{array}{l}2 \text { (Haddad et al., 2009; Sia } \\
\text { et al., 2007) }\end{array}$ \\
\hline \multicolumn{5}{|l|}{ D.R. Congo } \\
\hline Ethiopia & 1 (Regassa, 2011) & & $\begin{array}{l}3 \text { (Koricho et al., 2010; } \\
\text { Muluye et al., 2012; Setegn } \\
\text { et al., 2011) }\end{array}$ & \\
\hline Gabon & & & & 1 (Schwarz et al., 2009) \\
\hline Gambia & 1 (Telfer. et al., 2002) & & & \\
\hline Ghana & 1 (Bazzano et al., 2008) & & & \\
\hline Kenya & $\begin{array}{l}6 \text { (Birungi et al., 2011; } \\
\text { Chersich et al., 2009; } \\
\text { Fotso et al., 2009; Ochako } \\
\text { et al., 2011; Wanjira et al., } \\
\text { 2011; Warren et al., 2010) }\end{array}$ & & $\begin{array}{l}2 \text { (Kimani-Murage et al., } \\
\text { 2011; Kinuthia et al., } \\
\text { 2011) }\end{array}$ & \\
\hline Malawi & & & $\begin{array}{l}2 \text { (Bezner Kerr et al., } \\
\text { 2008; Chinkonde et al., } \\
\text { 2010) }\end{array}$ & \\
\hline Namibia & 1 (Zere et al., 2010) & & & \\
\hline Niger & & & 1 (Abba et al., 2010) & \\
\hline Nigeria & 1 (Etuk et al., 2000) & & $\begin{array}{l}3 \text { (Agunbiade and } \\
\text { Ogunleye, 2012; Davies- } \\
\text { Adetugbo, 1997; Imade et } \\
\text { al., 2010) }\end{array}$ & \\
\hline Uganda & 1 (Waiswa et al., 2008) & & $\begin{array}{l}2 \text { (Engebretsen et al., } \\
\text { 2010; Engebretsen et al., } \\
\text { 2007) }\end{array}$ & $\begin{array}{l}2 \text { (Babirye et al., 2011; } \\
\text { Nankabirwa et al., 2010) }\end{array}$ \\
\hline Senegal & 1 (Faye et al., 2010) & & $\begin{array}{l}1 \text { (Diagne-Guèye et al., } \\
\text { 2011) }\end{array}$ & \\
\hline Swaziland & & & 1 (Mazia et al., 2009) & \\
\hline
\end{tabular}




\begin{tabular}{|c|c|c|c|c|c|}
\hline \multicolumn{6}{|c|}{ Strategy } \\
\hline \multirow[t]{12}{*}{ Complications } & $\begin{array}{l}\text { Community } \\
\text { mobilization }\end{array}$ & $\begin{array}{l}\text { Intervention in health } \\
\text { services }\end{array}$ & $\begin{array}{l}\text { Community } \\
\text { interventions }\end{array}$ & Others & Total \\
\hline & & & & & 1 \\
\hline & $\begin{array}{l}1 \text { (Hounton et al., } \\
\text { 2009) }\end{array}$ & & & & 7 \\
\hline & & $\begin{array}{l}1 \text { (Matendo et al., } \\
\text { 2011) }\end{array}$ & & & \\
\hline & & & & & 4 \\
\hline & & & & & 1 \\
\hline & & & & & 1 \\
\hline & & & & & 1 \\
\hline & & $\begin{array}{l}1 \text { (Chersich et al., } \\
2009 \text { ) }\end{array}$ & & & 9 \\
\hline & & & 1 (Pagel et al., 2009) & & 3 \\
\hline & & & & & 1 \\
\hline & & & & & 1 \\
\hline \multirow{4}{*}{$\begin{array}{l}1 \text { \{Olusoga B O. and } \\
\text { Olusoji J D., } 2006 \\
\# 224 \text { \} }\end{array}$} & $\begin{array}{l}1 \text { (Olaniran et al., } \\
1997 \text { ) }\end{array}$ & & & & 6 \\
\hline & & 1 (Waiswa et al., 2008) & & & 6 \\
\hline & & & & & 2 \\
\hline & & & & & 1 \\
\hline
\end{tabular}


Factors

\begin{tabular}{|c|c|c|c|c|}
\hline Countries & $\begin{array}{l}\text { Utilization and skilled } \\
\text { attendance of health } \\
\text { services for mother and } \\
\text { newborn }\end{array}$ & Contraception & Breastfeeding and PMTCT & Immunization \\
\hline Tanzania & $\begin{array}{l}3 \text { (Magoma et al., 2010; } \\
\text { Mrisho et al., 2009; } \\
\text { Mrisho et al., 2008) }\end{array}$ & & $\begin{array}{l}3 \text { (Falnes et al., 2007; } \\
\text { Nkala and Msuya, 2011) }\end{array}$ & \\
\hline \multicolumn{5}{|l|}{ Zambia } \\
\hline Zimbabwe & & & $\begin{array}{l}2 \text { (Koyanagi et al., 2009; } \\
\text { Lunney et al., 2010) }\end{array}$ & \\
\hline $\begin{array}{l}\text { Africa/ } \\
\text { Developing } \\
\text { countries }\end{array}$ & $\begin{array}{l}1 \text { (MEASURE } \\
\text { Demographic Health } \\
\text { Survey, 2014) }\end{array}$ & $\begin{array}{l}1 \text { (Gebreselassi et al., } \\
2008)\end{array}$ & 1 (Tomasoni et al., 2011) & \\
\hline \multicolumn{5}{|l|}{$\begin{array}{l}\text { Agreements/ } \\
\text { Guidelines }\end{array}$} \\
\hline Reviews & $\begin{array}{l}3 \text { (Filippi et al., 2006; } \\
\text { Gabrysch and Campbell, } \\
\text { 2009; Richard et al., 2008) }\end{array}$ & & & \\
\hline Total & 22 & 2 & 24 & 5 \\
\hline
\end{tabular}

Table 1: Publications considered by subthemes and countries dealing with mother and newborn postpartum care in Africa 


\begin{tabular}{|c|c|c|c|c|c|}
\hline \multicolumn{6}{|c|}{ Strategy } \\
\hline Complications & $\begin{array}{l}\text { Community } \\
\text { mobilization }\end{array}$ & $\begin{array}{l}\text { Intervention in health } \\
\text { services }\end{array}$ & $\begin{array}{l}\text { Community } \\
\text { interventions }\end{array}$ & Others & Total \\
\hline \multirow[t]{6}{*}{1 (Pembe et al., 2009) } & & 1 (Mrisho et al., 2009) & 1 (Mrisho et al., 2008) & & 9 \\
\hline & & $\begin{array}{l}1 \text { (Hadley and Mary } \\
\text { Tuba, 2011) }\end{array}$ & & & 1 \\
\hline & & & $\begin{array}{l}1 \text { (Koyanagi A. et al., } \\
2009 \text { ) }\end{array}$ & & 3 \\
\hline & & 1 (Crowe et al., 2012) & & 1 (Binkin et al., 2011) & 5 \\
\hline & & $\begin{array}{l}2 \text { (Warren et al., 2006; } \\
\text { WHO, 2010) }\end{array}$ & & & 2 \\
\hline & 1 (Kumar et al., 2010) & $\begin{array}{l}3 \text { (Clements et al., } \\
\text { 2008; Hiller et al., } \\
\text { 2007; Raven et al., } \\
\text { 2011) }\end{array}$ & $\begin{array}{l}3 \text { (Kidney et al., 2009; } \\
\text { Schiffman. et al., } \\
\text { 2004(Sibley L. and } \\
\text { Sipe T., 2004)) }\end{array}$ & $\begin{array}{l}4 \text { (Blencowe et al., } \\
\text { 2011; Darmstadt et } \\
\text { al., 2005; Haws et } \\
\text { al., 2007; Lawn et al., } \\
\text { 2010) }\end{array}$ & 14 \\
\hline 2 & 3 & 11 & 6 & 5 & 80 \\
\hline
\end{tabular}




\section{Results}

According to DHS data on 23 African countries, the utilization of maternal services decreases along the continuum of care from antenatal visit to postpartum services (see Table 2): $74 \%$ of women have attended at least one antenatal visit; $46 \%$ have benefited from assisted childbirth and $36 \%$ have had a postnatal visit within two days of giving birth (MEASURE Demographic Health Survey, 20I4).

\begin{tabular}{|c|c|c|c|c|c|}
\hline Countries & $\begin{array}{c}\text { At least } 1 \\
\text { antenatal } \\
\text { visit }\end{array}$ & $\begin{array}{c}\text { Percentage } \\
\text { delivered by } \\
\text { a skilled } \\
\text { birth attendant }\end{array}$ & $\begin{array}{c}\text { Postnatal care } \\
\text { within the first } \\
\text { two days after } \\
\text { birth }\end{array}$ & $\begin{array}{l}\% \text { of newborn } \\
\text { babies } \\
\text { breastfed an } \\
\text { hour after the } \\
\text { birth }\end{array}$ & $\begin{array}{c}\% \text { of infants } \\
\text { exclusively } \\
\text { breastfed from } \\
0 \text { to } 6 \text { months }\end{array}$ \\
\hline Benin (2006) & 88 & 78 & 63 & 54 & 43 \\
\hline Burkina Faso (2010) & 98 & 67 & 72 & 42 & 24 \\
\hline Cameroon (2011) & 86 & 64 & 37 & 40 & 20 \\
\hline Chad (2004) & 43 & 21 & & 34 & 2 \\
\hline $\begin{array}{l}\text { Congo Brazzaville } \\
\text { (2012) }\end{array}$ & 93 & 94 & 64 & 24 & 21 \\
\hline D.R. Congo (2007) & 85 & 74 & & 48 & 36 \\
\hline Ethiopia (2011) & 43 & 10 & 7 & 52 & 32 \\
\hline Ghana (2008) & 95 & 59 & 68 & 52 & 63 \\
\hline Guinea (2005) & 82 & 38 & & 40 & 27 \\
\hline Kenya (2008-2009) & 92 & 44 & & 58 & 32 \\
\hline Liberia (2007) & 68 & 37 & 83 & 67 & 33 \\
\hline $\begin{array}{l}\text { Madagascar (2008- } \\
\text { 2009) }\end{array}$ & 96 & 44 & 46 & 72 & 30 \\
\hline Malawi (2010) & 98 & 71 & 43 & 95 & 70 \\
\hline Mali (2006) & 70 & 49 & & 46 & 38 \\
\hline Namibia (2006-2007) & 95 & 81 & 65 & 71 & 25 \\
\hline Niger (2006) & 46 & 33 & & 48 & 14 \\
\hline Nigeria (2008) & 58 & 39 & & 38 & 13 \\
\hline Rwanda (2010) & 98 & 69 & 18 & 71 & 76 \\
\hline Senegal (2010-2011) & 96 & 65 & 68 & 48 & 39 \\
\hline Sierra Leone (2008) & 87 & 42 & 58 & 51 & 11 \\
\hline Tanzania (2010) & 96 & 51 & 31 & 49 & 50 \\
\hline Uganda (2011) & 95 & 58 & 33 & 53 & 63 \\
\hline Zambia (2007) & 94 & 47 & 39 & 57 & 61 \\
\hline Average ${ }^{\star}$ & 74 & 46 & 36 & 49 & 32 \\
\hline
\end{tabular}

* We calculated the weighted arithmetic average by number of births for 2005 provided by the United Nations World Population Prospects 2012 (United Nations Department of Economic and Social Affairs Population Division: Population Estimates and Projections Section, 20I4).

Table 2: Continuum of care from antenatal to postpartum visits in 23 African countries 
We calculated the weighted arithmetic average by number of births for 2005 provided by the United Nations World Population Prospects 2012 (United Nations Department of Economic and Social Affairs Population Division: Population Estimates and Projections Section, 20I4).

The use of clinical services for children has improved substantially during the last two decades. The vaccination coverage for the bacillus Calmette-Guérin (BCG) was between 80 and $100 \%$ in most western and central African countries (World Health Organization :Global Health Observatory Data Repository). However, it did not automatically translate into the same degree of improvements in the utilization of maternal care services (World Health Organization: Global Health Observatory Data Repository).

\section{Factors associated with the utilization of mother and child postpartum services}

We analyzed the factors associated with the utilization of mother and newborn postpartum care services in sub-Saharan Africa.

\section{Socio-demographic factors}

Mothers' education: the higher the educational level of mothers, the more they attended health centres for postpartum services (Fotso et al., 2009; Gabrysch and Campbell, 2009; Gebreselassie et al., 2008; Nankabirwa et al., 20I0; Nigatu, 20II; Wanjira et al., 20II; Zere et al., 2010), respected the infant immunization schedule (Nankabirwa et al., 2010) and adopted a contraceptive method during postpartum (Gebreselassie et al., 2008). However, a high level of education in women decreased the practice of exclusive breastfeeding (Gebreselassie et al., 2008). Others found that it was positively correlated with late complementary feeding (Agunbiade and Ogunleye, 20I2; Kimani-Murage et al., 20II; Tomasoni et al., 20II).

Mothers' age: younger mothers tended to use maternal services more than older ones (Wanjira et al., 20II). The median duration of breastfeeding declined with increasing age (Gebreselassie et al., 2008).

Marital status: we found one paper studying the impact of polygamy on utilization of postpartum care (PPC). It showed a negative correlation between polygamy and PPC utilisation (Nigatu, 20II).

Profession: being employed hampered the prevention of mother-to-child transmission (PMTCT) of HIV (Muluye et al., 20I2), exclusive breastfeeding and feeding duration (Agunbiade and Ogunleye, 20I2; Gebreselassie et al., 2008). Also, household chores had a negative effect on infant immunization as they were causing delays and postponements (Schwarz et al., 2009). 
Geographic access, place of residence and delivery: lack of access to facilities because of long distances, absence of roads, or impassable roads (particularly during rainy seasons) can prevent utilization of services (Bazzano et al., 2008; Birungi et al., 20II; Dugas et al., 2009; Fadnes et al., 20II; Faye et al., 2010; Gabrysch and Campbell, 2009; Haddad et al., 2009; Magoma et al., 2010; Mrisho et al., 2008; O'Gorman et al., 2010; Regassa, 20II; Schwarz et al., 2009). Regional disparity in the provision of maternal health services including postpartum services was striking in several countries, particularly in Namibia (Zere et al., 2010). Immunization schedules were more respected in urban than in rural areas (Sia et al., 2007). Home births were more common in rural than in urban areas (Bazzano et al., 2008; Faye et al., 2010; Gabrysch and Campbell, 2009; Mrisho et al., 2009; Mrisho et al., 2008; Ochako et al., 20II; Zere et al., 2010) and were shown to increase the risk of HIV transmission (Imade et al., 20Io). Women in urban areas stopped breastfeeding earlier and more frequently adopted modern family planning compared to those in rural areas (Gebreselassie et al., 2008).

Cost and income: Lack of money for direct medical and transport costs was an issue for the utilization of postpartum services and PMTCT (Bazzano et al., 2008; Filippi et al., 2006; Gabrysch and Campbell, 2009; Mrisho et al., 2009; Mrisho et al., 2008; O'Gorman et al., 2010; Ochako et al., 20II; Telfer et al., 2002; Waiswa et al., 2008; Zere et al., 2010).

Household income was positively correlated with the adoption of modern family planning methods and infant immunization (Fadnes et al., 20II; Gebreselassie et al., 2008). Female income was linked to individual autonomy for taking the decision to visit health services (Babirye et al., 20II; Dugas et al., 2009; Fadnes. et al., 20II; Fotso et al., 2009; Magoma et al., 2010; Mrisho et al., 2008).

Access to information: many studies noted the low availability and access to information and knowledge on safe motherhood delivery and skilled birth attendance (Fotso et al., 2009; Gabrysch and Campbell, 2009; Magoma et al., 2010; Mrisho et al., 2009; Ochako et al., 20II; Wanjira, 20II). There was a lack of information during prenatal visits on some topics including, the need to deliver in a health facility, to visit postpartum services and to vaccinate the children (Dugas et al., 2009; Gabrysch and Campbell, 2009; Mrisho et al., 2009; Ochako et al., 20II; Sia et al., 2007; Telfer et al., 2002). A lack of knowledge about recognizing the danger signs of obstetric complications during the postpartum period, associated with other factors (education level, maternal age, number and place of deliveries, number of prenatal visits) prevented the timely use of health centres (Babirye et al., 20II; Etuk et al., 20I0; Gabrysch and Campbell, 2009; Magoma et al., 20I0; Mrisho et al., 2009; Mrisho et al., 2008; Ochako et al., 20II; Pembe et al., 2009; Schwarz et al., 2009). Further, the side effects of some vaccines (fever, diarrhoea, pain and swelling) sometimes discouraged mothers, causing them to abandon or postpone vaccinations (Babirye et al., 20II; Schwarz et al., 2009).

According to some literature, exposure to media coverage of the benefits of exclusive breastfeeding contributed to the diffusion of the practice among the population (Nkala and Msuya, 20II; Gebreselassie et al., 2008; Leshabari et al., 2007). 


\section{Beliefs and cultural practices}

Exclusive breastfeeding was shown to be constrained by socio-cultural representations (Abba et al., 2012; Bezner Kerr et al., 2008; Davies-Adetugbo, I997; Diagne-Guèye et al., 20II; Engebretsen et al., 20I0; Engebretsen et al., 2007; Hofmann et al., 2009; Lunney et al., 2010; Tomasoni et al., 20II). Grandmothers played a key role in the initiation of breastfeeding and weaning (Agunbiade and Ogunleye, 20I2; Bezner Kerr et al., 2008; Davies-Adetugbo, I997; Falnes et al., 20II). However, there was a lack of confidence in exclusive breastfeeding despite the knowledge that infants who were exclusively breastfed tended to be less sick (Koyanagi et al., 2009) and that almost all neonatal deaths occurring within the baby's first year of life were due to infections (Shapiro et al., 2007; Warren et al., 20Io). Mothers tended to introduce water, mixtures, infusions, decoctions and other dietary supplements in an effort to improve child survival (Agunbiade and Ogunleye, 20I2; Bezner Kerr et al., 2008; Davies-Adetugbo, I997; Hofmann; De Allegri et al., 2009). The duration and the intensity of breastfeeding varied considerably among women and communities (Davies-Adetugbo, I997; Gebreselassie et al., 2008).

Although the best practice is to keep the cord clean, the belief that traditional medications applied to the umbilical cord will help healing and protect the baby from sorcerers was widespread, especially as this was encouraged by some health workers (Waiswa et al., 2008).

Also, the resumption of sexual activity in connection with the recovery of menses or not were subject to individual and socio-cultural factors which determined the time at adoption of a contraceptive method in the postpartum period (Ganaba et al., 20Io; Gebreselassie et al., 2008).

The first vaccines were often perceived to be more important than the booster shots because in the case of the latter the older child was considered less vulnerable, which leads to a declining rate of vaccination coverage over time (Fadnes et al., 20II; Schwarz et al., 2009). Some mothers did not vaccinate if she and/or her children were malnourished, poorly dressed and sickly, for fear of being branded as bad or neglectful mothers. Some mothers were scared for their children at the health centre to hear other children crying and so left without consulting (Babirye et al., 20II; Schwarz et al., 2009).

\section{Other factors for maternal and child health services utilization}

Four other factors were identified that pertained to the utilization of postpartum services.

Utilization of maternal health services: the continuum of care from prenatal care onwards in health facilities was associated with later postpartum services utilization. The utilization of postpartum services for mothers was low in the absence of health complications (Magoma et al., 20I0; Mrisho et al., 2009; Nigatu, 20II; Wanjira et al., 20II) and for mothers with high parity (Nigatu, 20II; Wanjira et al., 20II). The more frequently and the earlier antenatal visits took place, the greater the probability of the mother attending a health centre in the postpartum period and benefiting from PMTCT (Dugas et 
al., 2009; Fadnes et al., 20II; Gabrysch and Campbell, 2009; Kinuthia et al., 20II; Mrisho et al., 2009; Ochako et al., 20II; Sia et al., 2007). Contraceptive use during the I2 month postpartum period was also positively associated with giving birth at a health facility (Gebreselassie et al., 2008).

Organization of services: organizational problems in health facilities such as lack of integrated services also led to low utilization of postpartum services (Bazzano et al., 2008; Faye et al., 2010; Gabrysch and Campbell, 2009; Haddad et al., 2009; Magoma et al., 2010; Mrisho et al., 2009; Mrisho et al., 2008; Ochako et al., 2006; Telfer et al., 2002; Waiswa et al., 2008). Attending postpartum services was hampered by poor provision of services, for instance at a previous delivery and at PMTCT and immunization services (Haddad et al., 2009; Schwarz et al., 2009; Sia et al., 2007).

PMTCT organisation: the utilization of maternal postpartum services by HIV-positive women was low (Birungi et al., 20II). Women who gave birth were often not tested for HIV/AIDS status (Imade et al., 2010). Women who tested positive did not always bring their children to the PCR (polymerase chain reaction) test, for various reasons (Imade et al., 2010; O'Gorman et al., 2010): (I) health workers lacked training in new PMTCT protocols and guidelines (Chinkonde et al., 2010; Fadnes et al., 2010); (2) absent or overworked health workers who were poorly paid or unpaid and lack of resources led to poor organization (Birungi et al., 20II; Leshabari et al., 2007; O'Gorman et al., 2010; Sprague et al., 20II); and (3) equipment and supplies such as antiretroviral drugs (ARVs), test kits, laboratory testing for $\mathrm{CD}_{4}$ count and PCR were not available (Sprague et al., 20II). Some women who were afraid of the HIV/AIDS test results refused the test, or denied its results (Koricho et al., 2010). The fear of being stigmatized by their families and the community or being abandoned by their husbands made some women hide their HIV status and therefore hampered the implementation of PMTCT (Muluye et al., 20I2; O'Gorman et al., 2010).

Immunization services: child immunization rates tended to increase in epidemic areas (Dugas et al., 2009). The timing of immunization programmes (date and time) in health centres was not always convenient for all (Schwarz et al., 2009). Further, immunization programmes suffered from the lack of vaccines, owing to irregular supply and poor functioning of the cold chain (Haddad et al., 2009; Schwarz et al., 2009; Sia et al., 2007). A key factor here was the leadership of the healthcare team in the management of immunization activities: influencing the prioritization of vaccination in the action plans, supervision, community mobilization, awareness and coordination, and monitoring of children vaccinated (Haddad et al., 2009). Combining healthcare and other activities such as the distribution of food and insecticide-treated nets contributed to promoting the utilization of immunization services, despite some adverse effects related to funding and project termination (Fadnes et al., 20II; Sia et al., 2007). 
The next section will present a range of types of intervention aimed at improving postpartum child and maternal care found in the literature.

\section{Strategies for improving mother and child postpartum care}

This review identified interventions at the household, community and/or health service levels that had an important positive effect on neonatal, perinatal and maternal mortality (Blencowe et al., 20II; Crowe et al., 2012; Haws et al., 2007; Hounton et al., 2009; Kidney et al., 2009; Mrisho et al., 2008; Olaniran et al., I997; Pagel et al., 2009; Schiffman et al., 2010; Sibley and Sipe, 2004). A combination of several strategies was examined in the studies, which comprised mainly of community mobilization, employment of community health workers (CHWs) and village midwives, and the enhancement of health facilities services.

\section{Community mobilization}

Some studies showed that the efforts aimed at encouraging behavioural change towards proper newborn care practices at the community level were very successful and contributed to newborn survival (Kidney et al., 2009). Counselling availability at the community level on the treatment of newborn fever at childbirth, appropriate hygiene for mother and child after giving birth and the benefits of exclusive and early breastfeeding were key issues (Haws et al., 2007; Hounton et al., 2009; Mrisho et al., 2008; Olaniran et al., I997). Postpartum family planning counselling did not seem to raise contraceptive utilization (Hiller et al., 2007). The frequency of postpartum contraceptive use was low, even among women who had indications of extreme clinical severity, such as signs of shock or organ failure at delivery (Ganaba et al., 2010).

Using women's discussion groups to identify perinatal problems and formulate strategies contributed to reduced neonatal mortality, up to $30 \%$ in some cases (Kumar et al., 20I0). Such discussion groups had a high impact on improving antenatal care, care during the intra-partum period, umbilical cord care and on the prevalence of women using healthcare, as well as having a moderate impact on breastfeeding practices. However, these results and their impact on neonatal mortality were not replicated to the same degree upon scaling-up the intervention (Kumar et al., 2010).

Sensitization of communities and women through appropriate guidance, peer support, advocacy and access to information was shown to help in promoting and implementing exclusive breastfeeding (Agunbiade and Ogunleye, 20I2; Diagne-Guèye et al., 20II; Hofmann et al., 2009; Nkala and Msuya, 20II). Community-level breastfeeding promotion by peers and in-service training in the community (Fadnes et al., 20II) and at the health facility level (Setegn et al., 20II; Waiswa et al., 2008; Kemigisa et al., 2008) could be demonstrated to increase the rate of breastfeeding. The community was also revealed to play a role in encouraging immunization (Sia et al., 2007).

Some studies recommended that community mobilization could be integrated into programmes aimed at strengthening the health system where health centres also managed community provision of services (Blencowe et al., 20II; Pagel et al., 2009). 


\section{Employment of $\mathrm{CHWs}$ and village midwives}

In remote areas, CHWs and village midwives were often the main providers of birth and postpartum services. Therefore, some papers noted that they should be trained in, for instance, mitigating the risks associated with home-births through the provision of utero tonics, and the administration of misoprostol for haemorrhage and antibiotics for infections. Further, equipment should be available (e.g. delivery kits) (Crowe et al., 2012; Kidney et al., 2009).

However, the approval of Traditional Birth Attendants (TBAs) was not universal. Guidelines recommended that they be trained to identify high-risk pregnancies and provide appropriate referrals. Research shows the importance of involving TBAs in some aspects of PMTCT services as they can provide healthy delivery with less risks, support in monitoring treatment and in referring infected women to the health centres (Birungi et al., 20II; O'Gorman et al., 2010).

\section{Health facilities' strategies to improve postpartum care}

The potential for postnatal care to have a substantial effect on neonatal mortality was shown to be greater than that of antenatal care and similar to that of intrapartum care, but at lower cost (Darmstadt et al., 2005). This revealed the importance of strengthening postpartum services in the interests of both mothers and children (Binkin et al., 20II; Chersich et al., 2009; Clements. et al., 2008; Darmstadt et al., 2005; Hadley and Mary Tuba, 20II; Matendo et al., 20II; Mrisho et al., 2009; Waiswa et al., 2008; Warren et al., 2006). Health providers training mothers in essential newborn care, including followup and capacity building, reduced neonatal deaths within the baby's first week of life (Matendo et al., 20II; Mazia et al., 2009). Sines et al. (2007) recommended that household practices regarding mother and newborn care should be enhanced by health services. The use of Kangaroo Mother Care (KMC) in health centres was shown to reduce neonatal deaths of newborns with low-weight at birth $(<2000 \mathrm{~g}$ ) by more than $50 \%$ (Lawn et al., 20I0). Women's access to childcare services offered an opportunity to provide or facilitate access to sexual and reproductive health services and to encourage their long-term utilization (Chersich et al., 2009). A study from our review suggested that adequate maternal care should be delivered during the first year of postpartum within childcare services (Chersich et al., 2009). Experiences in integrating care interventions such as vitamin A, antenatal services, mosquito nets, anthelminthic, mebendazole with immunization services were identified as successful alternative strategies (Clements et al., 2008). The outreach services and health education used for family and community health through the promotion of key family practices generated further demand for qualified care according to Darmstadt et al. (2005).

The quality of maternal and infant care within health centres and of the healthcare system in general proved to be important and therefore in need of support (Newlands et al., 2008; Richard et al., 2008; WHO et al., 2010), mostly by strengthening care standards and reviewing maternal deaths and near-deaths (Darmstadt et al., 2005; Pagel et al., 2009; Raven et al., 20II; WHO, 20I0). While immediate postnatal care provided within 48 hours 
of childbirth was identified as being very important (Wang et al., 20II), these services were generally under-used or unavailable. Several authors have shown that efforts should be made in health system policy and planning to provide these services to mothers and newborns (Binkin et al., 20II; Chersich. et al., 2009; Clements et al., 2008; Matendo et al., 20II; Mrisho et al., 2009; Waiswa et al., 2008; Warren et al., 2006). A rapid response to danger signs, such as maternal infection, reduced the risk of maternal mortality per infection by 90\% (WHO, 20I0).

Investments in maternal care services were cost-effective for the prevention and management of emergencies, and reduction of maternal deaths (Brazier et al., 2009). Darmstadt et al., (2005) stated that improving health coverage through the expansion of mother and child healthcare facilities would be a necessary step to achieve the global reduction of neonatal mortality planned by the Millennium Development Goal (MDG 4).

\section{Discussion}

The literature review on postpartum care in Africa allowed us to identify factors associated with the effective utilization of mother-and-child care services during the postpartum period, and the strategies used to improve them. The low educational level of the parents (especially of mothers), beliefs, cultural and religious practices, lack of financial and material resources and low quality of health services was shown to impede access to qualified care in health centres. The literature advocated the design and testing of innovative strategies for changing behaviour and provision of postnatal care after childbirth.

Factors associated with the utilization of postpartum services have serious implications in terms of prevention and quick detection of danger signs, which decreases postpartum maternal morbidity and mortality. The involvement of other societal sectors such as the educational system to promote the use of postpartum services and safe practices in postpartum care such as the organization of (medical) transport to avoid home births were suggested as necessities for efficiently improving postpartum services. The fact that educated women have a better understanding of health issues, greater autonomy and decision-making power, and better access to information highlights the role of female education in health and global development. It was also recommended that postpartum education should be included within the sexual, maternal and family modules in schools and literacy programmes in local languages.

It was advocated that the promotion of postpartum services should use all available health information channels such as radio spots, television and town criers; advocacy campaigns using theatre plays should be implemented in settings with low utilization rate of postpartum services and detrimental beliefs and practices among the population. The communication plan target should be the leaders, men, women in the postpartum period and women with experience in child birth. Group discussions should be organized with health workers, CHWs, village midwives and peer volunteers. Individual counselling must be reinforced with women at antenatal care, child birth and postpartum services. 
Although the distances between health facilities and the population are gradually shrinking, the review emphasized the need for infrastructure reinforcement particularly in settings with limited access to, and provision of, postpartum services. The access must also be strengthened by the construction and maintenance of roads and bridges, especially to allow better access during the rainy season.

Although outreach services can bring healthcare closer to the population, it is more often used for newborns and children than for maternal postpartum care due to practical difficulties in implementation. However, some authors have emphasized that some services such as counselling for mothers and checking for fever, anaemia and monitoring blood pressure do not require important logistics and could effectively contribute to the rapid recognition of warning signs in mothers and newborns.

The literature review shows clearly that national policies on postpartum care should be evaluated and revised taking into account standards and international recommendations through health system building blocks. Health workers' basic training, retraining and supervision should make a difference on the content quality and timing of postpartum service packages. In order to reduce the main causes of death during the postpartum period, interventions should be streamlined to WHO guidelines: treatment of maternal anaemia, detection and management of postpartum sepsis (serious infections after birth), initiation of early breastfeeding (within the first hour), exclusive breastfeeding for six months, hygienic cord and skin care. This review has highlighted missed opportunities for mother-and-child caretaking, which can be bridged by the utilization of village midwives and the integration of postpartum services for mothers within child clinics.

One potential measure recommended by many would be subsidizing maternal postpartum services or delivering them free of charge to remove any financial barriers, similarly to what has been implemented for obstetric and immunization services in most African countries.

The study has several limitations. First, there are few studies that look exclusively into maternal and child healthcare in the postpartum period. This period is generally studied together with antenatal period and childbirth.

The exclusive focus on Africa is the second weakness. The article could have learned from the experience in other developing regions such as South Asia where in the case of well-developed curative postpartum care within households and communities, neonatal and perinatal mortality were effectively reduced (Agrawal et al., 20I2; Baqui et al., 2008; Baqui et al., 2009; Kumar et al., 2010; Schiffman et al., 2010). The replicability of the curative package provision for neonatal interventions in most African communities is nevertheless an issue as village midwives and community health workers are few in number and usually illiterate.

While both are highly relevant in most sub-Saharan African countries, postpartum care and PMTCT strategies should be different. Throughout our literature review, we noticed an imbalance in the research topics, as more attention was being addressed to the challenge of PMTCT in comparison with other components of postpartum care. 


\section{Conclusion}

This review has highlighted the main results from several studies on the associated factors and strategies for postpartum care in Africa. Although strategies known to be effective in reducing maternal and infant morbidity and mortality exist and have been implemented in sub-Saharan Africa, the statistics are alarming and below legitimate expectations. The studies highlight the need for the integration of maternal postpartum care within the combination of essential postpartum interventions at the level of households, communities and health centres.

\section{Competing interests}

The authors declare that they have no conflicting interests.

\section{The authors' contributions}

DBY conducted the literature review and paper drafting; SK contributed to design the study, coordinated the review process and contributed to the manuscript revision; AG contributed to the paper drafting; JAK conducted the literature review and contributed to the paper. ED, OD and MT provided inputs to the paper. All the authors approved the final version of the paper.

\section{Figure legends}

Figure I Literature review flow chart following the PRISMA methodology.

\section{Acknowledgements}

This work was funded by the Pole d'information en santé maternelle et néonatale (PISMAN), an initiative of the United Nations Population Fund (UNFPA) to share, and capitalize on, information and experience of countries in order to ensure better implementation of effective strategies in the Francophone sub-region of western and central Africa.

It has also benefited from the MOMI project 'Missed Opportunities in Maternal and Infant Health: reducing maternal and newborn mortality and morbidity in the year after childbirth through combined facility and community-based interventions'. MOMI has received funding from the European Union's Seventh Framework Programme [FP7/200720I3] under grant agreement $n^{\circ}$ 265448. MOMI is a collaborative project between the Institut de Recherche en Sciences de la Santé (Burkina Faso), the International Centre for Reproductive Health at Ghent University (Belgium), the International Centre for Reproductive Health (Kenya), the Parent and Child Initiative of the Kamuzu Central Hospital and Ministry of Health (Malawi), the International Centre for Reproductive Health (Mozambique), the Eduardo Mondlane University (Mozambique), the Medical Faculty of the University of Porto (Portugal) and the University College of London (United Kingdom). $\mathrm{DBY}$ is a MOMI project PhD student.

The authors wish to thank the Vienna Institute of Demography (Austrian Academy of Sciences) for hosting DBY. 


\section{References}

Abba, A., De Koninck, M. and Hamelin, A.M. (2010). A qualitative study of the promotion of exclusive breastfeeding by health professionals in Niamey, Niger. International Breastfeeding Journal, $5(8)$. doi:10.II86/1746-4358-5-8.

Agrawal, P., Agrawal,S., Ahmed, S., Darmstadt, G., Williams, E, Rosen, H. et al. (2012). Effect of knowledge of community health workers on essential newborn health care: a study from rural India. Health Policy and Planning, 27, II5-I26.

Agunbiade, O.M. and Ogunleye, O.V. (2012). Constraints to exclusive breastfeeding practice among breastfeeding mothers in Southwest Nigeria: implications for scaling up. International Breastfeeding Journal, 7(5). doi:Io.II86/1746-4358-7-5.

Babirye, J.N., Rutebemberwa, E., Kiguli, J., Wamani, H., Nuwaha, F. and Engebretsen, I. (20II). More support for mothers: a qualitative study on factors affecting immunisation behaviour in Kampala, Uganda. BMC Public Health, 11(723). doi:I0.II86/I47I-2458-II-723.

Baqui, A., El-Arifeen, S., Darmstadt, G., Ahmed, S., Williams, E., Seraji, H. et al. (2008). Effect of community-based newborn-care intervention package implemented through two service-delivery strategies in Sylhet district, Bangladesh: a cluster-randomised controlled trial. The lancet, 371, 1936I944.

El-Arifeen, S., Williams, E., Ahmed, S., Mannan, I., Rahman, S. et al. (2009). Effectiveness of Home-based Management of Newborn Infections by Community Health Workers in Rural Bangladesh. Pediatr Infect Dis J., 28(4), 304-310. doi:Io.Io97/INF.oborze31819o6ge8

Bazzano, A.N., Betty Kirkwood, B., Tawiah-Agyemang, C., Seth Owusu-Agyei, S. and Adongo, P. (2008). Social costs of skilled attendance at birth in rural Ghana. International Journal of Gynecology and Obstetrics, 102, 9I-94.

Bezner, Kerr, R., Dakishoni, L., Shumba, L., Msachi, R. and Chirwa, M. (2008). "We Grandmothers Know Plenty": Breastfeeding, complementary feeding and the multifaceted role of grandmothers in Malawi. Social Science \& Medicine, 66, 1095-II05.

Binkin, N., Chopra, M., Simen-Kapeu, A. and Westhof, D. (20II). Do improvements in outreach, clinical, and family and community-based services predict improvements in child survival? An analysis of serial cross-sectional national surveys. BMC Public Health 2011, 11(456).

Birungi, H., Obare, F., Kwaak, A. and Jane Harriet Namwebya, J.H. (20II). Maternal Health Care Utilization Among HIV-Positive Female Adolescents in Kenya. International Perspectives on Sexual and Reproductive Health, 37(3), 143-I49. doi: 10.1363/37143II

Blencowe, H., Cousens, S., Mullany, LC., Lee, C., Kerber, K., Wall S. et al. (20rI). Clean birth and postnatal care practices to reduce neonatal deaths from sepsis and tetanus: a systematic review and Delphi estimation of mortality effect. BMC Public Health, 11(Suppl 3)(SII).

Brazier, E., Andrzejewski, C., Perkins, M.E., Themmen, E.M., Knight, R.J. and Bassane, B. (2009). Improving poor women's access to maternity care: Findings from a primary care intervention in Burkina Faso. Social Science \& Medicine, 69, 682-69o.

Chersich, M.F., Kley, N., Luchters, S., Njeru, C., Yard, E., Othigo, M. et al. (2009). Maternal morbidity in the first year after childbirth in Mombasa Kenya; a needs assessment. BMC Pregnancy and Childbirth, 9(5I).

Chinkonde, J.R., Sundby, J., Paoli, M. and Thorsen, V.C. (2010). The difficulty with responding to policy changes for HIV and infant feeding in Malawi. International Breastfeeding Journal, 5(II). doi:I0.II86/1746-4358-5-II.

Clements, C.J., Nshimirimandab, D. and Gasasirab, A. (2008). Using immunization delivery strategies to accelerate progress in Africa towards achieving the Millennium Development Goals. Vaccine, 26, I926-I933.

Crowe, S., Utley, M., Costello, A. and Pagel, C. (2012). How many births in sub-Saharan Africa and South Asia will not be attended by a skilled birth attendant between 2011 and 2015? BMC Pregnancy and Childbirth 2012, 12(4). 
Darmstadt, G.L., Bhutta, Z.A., Cousens, S., Adam, T., Walker, N. and Luc de Bernis, for the Lancet Neonatal Survival Steering Team. (2005). Evidence-based, cost-effective interventions: how many newborn babies can we save? The Lancet, 365, 977-988.

Davies-Adetugbo, A.A. (1997). Sociocultural factors and the promotion of exclusive breastfeeding in rural Yoruba communities of Osun State, Nigeria. Social Science \& Medicine, 45, II3-I25.

Diagne-Guèye, N.R., Diack-Mbaye, A., Dramé, M., Diagne, I., Fall, A.L., Camara, B. et al. (2011). Connaissances et pratiques de mères sénégalaises vivant en milieu rural ou suburbain sur l'alimentation de leurs enfants, de la naissance à l'âge de six mois. Journal de pédiatrie et de puériculture, 24, I6I-I66.

Dugas, M., Dubé, E., Kouyaté, B., Sanou, A. and Bibeau, G. (2009). Portrait of a lengthy vaccination trajectory in Burkina Faso: from cultural acceptance of vaccines to actual immunization. BMC International Health and Human Rights, 9 (Suppl 1)(S9). doi:Io.II86/I472-698X-9-SI-S9.

Engebretsen, I., Moland, K.M., Nankunda, J., Karamagi, C.A., Tylleskär, T. and Tumwine, J.K. (2010). Gendered perceptions on infant feeding in Eastern Uganda: continued need for exclusive breastfeeding support. International Breastfeeding Journal, 5(13). doi:I0.II86/1746-4358-5-I3

Engebretsen, I., Waman, H., Karamagi, C., Semiyaga, N., Tumwine, J. and Tylleskär, T. (2007). Low adherence to exclusive breastfeeding in Eastern Uganda: a community-based cross-sectional study comparing dietary recall since birth with 24-hour recall. BMC Pediatrics, 7(Io), I2.

Etuk, S.J., Itam, I.H. and Asuquo, E.E.J. (2000). Morbidity and mortality in booked women who deliver outside orthodox health facilities in Calabar, Nigeria. Acta Tropica, 75, 309-313.

Fadnes, L.T., Engebretsen, I.M., Moland, K.M., Nankunda, J., Tumwine, J.K. and Tylleskär, T. (2010). Infant feeding counselling in Uganda in a changing environment with focus on the general population and HIV-positive mothers - a mixed method approach. BMC Health Services Research, 10(260). doi:10.II86/1472-6963-10-26o.

Fadnes, L.T., Jackson, D., Engebretsen, I., Zembe, W., Sanders, D., Sommerfelt, H. et al. (20II). Vaccination coverage and timeliness in three South African areas: a prospective study. BMC Public Health, 11(404). doi:I0.II86/I47I-2458-II-404.

Falnes, E.F., Moland, K.M., Tylleskär, T., Manuela de Paoli, M., Leshabar, S.C. and Engebretsen, I. (20II). The potential role of mother-in-law in prevention of mother-to-child transmission of HIV: a mixed methods study from the Kilimanjaro region, northern Tanzania. BMC Public Health, 11(55I). doi:I0.II86/I47I-2458-II-55I.

Faye, A., Faye, M., Bâ, I.O., Ndiaye, P. and Tal-Di A. (20I0). Facteurs déterminant le lieu d'accouchement chez des femmes ayant bénéficié au moins d'une consultation prénatale dans une structure sanitaire (Sénégal). Revue d'Epidémiologie et de Santé Publique, 58, 323-329.

Filippi, V., Ronsmans, C., Campbell, O., Graham, W., Mills, A., Borghi, J., et al. (2006). Maternal health in poor countries: the broader context and a call for action. Lancet, 368, I535-154I.

Fotso, J.C., Ezeh, A.C. and Essendi, H. ( 2009). Maternal health in resource-poor urban settings: how does women's autonomy influence the utilization of obstetric care services? Reproductive Health, 6(9). doi:I0.II86/1742-4755-6-9.

Gabrysch, S. and Campbell, O. (2009). Still too far to walk: Literature review of the determinants of delivery service use. BMC Pregnancy and Childbirth, 9(34). doi:Io.II86/I47I-2393-9-34.

Ganaba, R., Marshall, T., Sombié, I., Baggaley, R.F., Ouédraogo, T.W. and Filippi, V. (2010). Women's sexual health and contraceptive needs after a severe obstetric complication ("near-miss"): a cohort study in Burkina Faso. Reproductive Health, 7(22). doi: Io.1186/1742-4755-7-22.

Gebreselassie ,T., Rutstein, S.O. and Mishra, V. (2008). Contraceptive Use, Breastfeeding, Amenorrhea and Abstinence During the Postpartum Period: An Analysis of Four Countries, DHS Analytical Studies (Vol. No. I4). Calverton, Maryland, USA: Macro International Inc.

Haddad,S., Bicaba, A., Feletto, M., Taminy, E., Kaboré, M., Ouédraogo, B. et al. (2009). System-level determinants of immunization coverage disparities among health districts in Burkina Faso: a multiple case study. BMC International Health and Human Rights, 9 (Suppl I)(SI5). doi:Io.II86/I472-698X9 -SI-SI5. 
Hadley, M.B. and Mary Tuba, M. (20II). Local problems, local solutions: an innovative approach to investigating and addressing causes of maternal deaths in Zambia's Copperbelt. Reproductive Health, $8(17)$.

Haws, R., Thomas A.,Bhutta, Z.A. and Darmstadt, G.L. (2007). Impact of packaged interventions on neonatal health: a review of the evidence. Health Policy and Planning, 22, 193-215.

Hiller, J.E., Griffith, E. and Jenner, F. (2007). Education for contraceptive use by women after childbirth (Review). The Cochrane Library (Issue 4).

Hofmann, J., De Allegri, M., Sarker, M., Sanon, M. and Böhler, T. (2009). Breast milk as the "water that supports and preserves life" - socio-cultural constructions of breastfeeding and their implications for the prevention of mother to child transmission of HIV in sub-Saharan Africa. Health Policy, 89, 322-328.

Hounton, S., Byass, P. and Brahima, B. (2009). Towards reduction of maternal and perinatal mortality in rural Burkina Faso: communities are not empty vessels. Global Health Action, 2 (incl. Supplements).

ICD-ro Version 2010. (2010). International Statistical Classification of Diseases and Related Health Problems, 10th Revision.

Imade, P.E., Uwakwe, N.O., Omoregie, R. and Eghafona, N.O. (2010). Effect of Prevention of the Mother to Child Transmission Program on the Prevalence of Postnatal HIV Infection in Benin City, Nigeria. Fooyin Journal of Health Sciences, 2, 58-6r.

Kassebaum, N.J., Bertozzi-Villa, A., Coggeshall, M., Shackelford, K., Steiner, C., Heuton, K. et al. (2014). Global, regional, and national levels and causes of maternal mortality during 1990-2013: a systematic analysis for the Global Burden of Disease Study 2013. The Lancet, So140(6736(I4)). doi:Io.Ior6

Kidney, E., Winter, H.R., Khan, K.S., Gülmezoglu, A.M., Meads, C.A., Deeks J. et al. (2009). Systematic review of effect of community-level interventions to reduce maternal mortality. BMC Pregnancy and Childbirth, 9(2).

Kimani-Murage, E.W., Madise, N.J., Fotso, J.C., Kyobutungi, C., Mutuab, M.K., Gitau, T.M. et al. (20II). Patterns and determinants of breastfeeding and complementary feeding practices in urban informal settlements, Nairobi Kenya. BMC Public Health, 11(396). doi:Io.II86/I47I-2458-II-396.

Kinuthia, J., Kiarie J.N., Farquhar, C., Richardson, B.A., Nduati, R., Mbori-Ngacha, D. et al. (20II). Uptake of prevention of mother to child transmission interventions in Kenya: health systems are more influential than stigma. Journal of the International AIDS Society, 14(6I). doi:I0.II86/I758-2652-I4-6I.

Koricho, A.T., Moland, K.M. and Blystad, A. (2010). Poisonous milk and sinful mothers: the changing meaning of breastfeeding in the wake of the HIV epidemic in Addis Ababa, Ethiopia. International Breastfeeding Journal, 5-I2. doi:Io.II86/I746-4358-5-I2.

Koyanagi, A., Humphrey, J.H., Moulton, L.H., Ntozini, R., Mutasa, K., Iliff, P. et al. (2009). Effect of early exclusive breastfeeding on morbidity among infants born to HIV-negative mothers in Zimbabwe. Am J Clin Nutr, 89, I375-I382.

Kumar, V., Kumar, A. and Darmstadt, G. (2010). Behavior Change for Newborn Survival in ResourcePoor Community Settings: Bridging the Gap Between Evidence and Impact. Semin Perinatol, 34, 446-46r.

Lawn, J., Mwansa-Kambafwile, J., Horta, B., Barros, F. and Cousens S. (2010). 'Kangaroo mother care' to prevent neonatal deaths due to preterm birth complications. International Journal of Epidemiology, 39, I44-I54.

Leshabari, S.C., Blystad, A., Paoli, M. and Moland, K.M. (2007). HIV and infant feeding counselling: challenges faced by nurse-counsellors in northern Tanzania. Human Resources for Health. 5(I8). doi:I0.II86/I478-449I-5-I8.

Lunney, K.M., Iliff, P., Mutasa, K., Ntozini, R., Magder, L.S., Lawrence, H. Moulton, L.H. et al. (2010). Associations between Breast Milk Viral Load, Mastitis, Exclusive Breast-Feeding, and Postnatal Transmission of HIV. Clinical Infectious Diseases, 50, 762-769. 
Magoma, M., Requejo, J., Campbell, O.M., Cousens, S. and Filippi, V. (2010). High ANC coverage and low skilled attendance in a rural Tanzanian district: a case for implementing a birth plan intervention. BMC Pregnancy and Childbirth, 10(13). doi:I0.1186/I471-2393-I0-13.

Matendo, R., Engmann, C., Ditekemena, J., Gado, J., Tshefu, A., Kinoshita, R. et al. (20II). Reduced perinatal mortality following enhanced training of birth attendants in the Democratic Republic of Congo: a time-dependent effect. BMC Medicine, 9(93).

Mazia, G., Narayanan, I., Warren, C., Mahdi, M., Chibuye, P., Walligo, A. et al. (2009). Integrating quality postnatal care into PMTCT in Swaziland. Global Public Health. Global Public Health, 4(3), 253-270. doi: $10.1080 / 17441690902769669$.

MEASURE Demographic Health Survey. (20I4). STAT compiler BUILDING TABLES WITH DHS DATA: MEASURE Demographic Health Survey.

Moher, D., Liberati, A., Tetzlaff, J., Altman, D. and The PRISMA Group, Preferred Reporting Items for Systematic Reviews and Meta-Analyses: The PRISMA Statement. PLoS Med:, 2009. 6((7)).

Mrisho, M., Obrist, B., Schellenberg, J.A., Haws, R.A., Adiel, K., Mushi, A.K., Mshinda, H. et al. (2009). The use of antenatal and postnatal care: perspectives and experiences of women and health care providers in rural southern Tanzania. BMC Pregnancy and Childbirth, g(Io).

Mrisho, M., Schellenberg, J.A., Mushi, A.K., Obrist, B., Mshinda, H., Tanner, M. et al. (2008). Understanding home-based neonatal care practice in rural southern Tanzania. Transactions of the Royal Society of Tropical Medicine and Hygiene, 102, 669-678.

Muluye, D., Woldeyohannes, D., Gizachew, M. and Tiruneh, M. (2012). Infant feeding practice and associated factors of HIV positive mothers attending prevention of mother to child transmission and antiretroviral therapy clinics in Gondar Town health institutions, Northwest Ethiopia. BMC Public Health, 12(240). doi:I0.II86/I47I-2458-I2-240.

Nankabirwa, V., Tylleskär, T., Tumwine, J.K. and Sommerfelt, H. and Promise-ebf Study Group. (2010). Maternal education is associated with vaccination status of infants less than 6 months in Eastern Uganda: a cohort study. BMC Pediatrics, 10(92). doi:I0.II86/I47I-243I-I0-92.

Newlands, D., Yugbare Belemsaga, D., Ternent, L., Hounton, S. and Chapman, G. (2008). Assessing the costs and cost effectiveness of a skilled care initiative in rural Burkina Faso. Tropical Medicine and International Health, 13 (SUPPL), 6I-67.

Nigatu, R. (20II). Antenatal and postnatal care service utilization in southern Ethiopia: a populationbased study. African Health Sciences, 11, 390-397.

Nkala, T.E. and Msuya, S.E. (20II). Prevalence and predictors of exclusive breastfeeding among women in Kigoma region, Western Tanzania: a community based cross-sectional study.. International Breastfeeding Journal, 6(17). doi:Io.1186/1746-4358-6-17.

O'Gorman, D.A., Nyirenda, L.J., Theobald S.J. (2010). Prevention of mother-to-child transmission of HIV infection: Views and perceptions about swallowing nevirapine in rural Lilongwe, Malawi. BMC Public Health, 10(354). doi: I0.II86/147I-2458-10-354.

Ochako, R., Fotso, J.C., Ikamari, L. and Khasakhala, A. (20II). Utilization of maternal health services among young women in Kenya: Insights from the Kenya Demographic and Health Survey, 2003. BMC Pregnancy and Childbirth, 11(I). doi:Io.II86/I47I-2393-II-I.

Olusoga, B O. and Olusoji, J D. (2006). Neonatal jaundice and its management: knowledge, attitude and practice of community health workers in Nigeria. BMC Public Health, doi:10.1186/1471-2458-6-19, 6:(I9).

Olaniran, N., Offiong, S., Ottong, S., Asuquo E. and Duke F. (1997). Mobilizing the community to utilize obstetric services, Cross River State, Nigeria. International Journal of Gynecology \& Obstetrics, 59(Suppl. 2), Si8I-Si89.

Pagel, C., Lewycka, S., Colbourn, T., Mwansambo, C., Meguid, T., Chiudzu, G. et al. (2009). Estimation of potential eff ects of improved community-based drug provision, to augment health-facility strengthening, on maternal mortality due to post-partum haemorrhage and sepsis in sub-Saharan Africa: an equity-eff ectiveness model. Lancet, 374, I44I-I448. 
Pembe, A.B., Urassa, D.P., Carlstedt, A., Lindmar, G., Lennarth Nyström, L. and Darj, E. (2009). Rural Tanzanian women's awareness of danger signs of obstetric complications. BMC Pregnancy and Childbirth, 9(I2). doi:I0.I186/I47I-2393-9-I2.

Raven, J., Hofman, J., Adegoke, A. and Broek, N. (20II). Methodology and tools for quality improvement in maternal and newborn health care. International Journal of Gynecology and Obstetrics, 114, 4-9.

Regassa, N. (20II). Antenatal and postnatal care service utilization in southern Ethiopia: a populationbased study. African Health Sciences, 11, 390-397.

Richard, F., Writter, S. and De Brouwere, V. (2008). Réduire les barrières financières aux soins obstrétricaux dans les pays à faibles ressources. Studies in Health Services Organisation \& Policy, 25, 340.

Schiffman, J., Darmstadt, G., Agarwal, S. and Baqui, A. (2010). Community-Based Intervention Packages for Improving Perinatal Health in Developing Countries: A Review of the Evidence. Semin Perinatol, $34,462-476$.

Schwarz, N.G., Gysels, M., Pell, C., Gabor, J., Schlie, M., Issifou, S. et al. (2009). Reasons for non-adherence to vaccination at mother and child care clinics (MCCs) in Lambaréné, Gabon. Vaccine, 27, 537I-5375.

Setegn, T., Gerbaba, M. and Belachew, T. (20II). Determinants of timely initiation of breastfeeding among mothers in Goba Woreda, South East Ethiopia: A cross sectional study. BMC Public Health, 11(217). doi:I0.II86/I47I-2458-II-2I7.

Shapiro, R.L., Lockman, S., Kim, S., Smeaton, L., Rahkola, J.T., Thior, I. et al. (2007). Infant Morbidity, Mortality, and Breast Milk Immunologic Profiles among Breast-Feeding HIV-Infected and HIVUninfected Women in Botswana. The Journal of Infectious Diseases, 196, 562-569.

Sia, D., Kobiané, J.F., Sondo, B.K. and Fournier, P. (2007). Les facteurs individuels et du milieu de vie associés à la vaccination complète des enfants en milieu rural au Burkina Faso: une approche multiniveau. Cahiers Santé, 17, 20I-206.

Sibley, L. and Sipe, T. (2004). What can a meta-analysis tell us about traditional birth attendant training and pregnancy outcomes? Midwifery 20, 51-60.

Sines, E., Syed, U., Wall, S. and Worley, H. (2007) Postnatal care: A critical opportunity to save mothers and newborns. Saving newborn lives. Washington: Save the Children Saving Newborn Lives and Population Reference Bureau.

Sprague, C., Chersich, M. and Black, V. (20II). Health system weaknesses constrain access to PMTCT and maternal HIV services in South Africa: a qualitative enquiry. AIDS Research and Therapy, 8(Io). doi:I0.1186/1742-6405-8-10

Telfer, M.L., Rowley, J.T. and Walraven, G.E.L. (2002). Experiences of Mothers with Antenatal, Delivery and Postpartum Care in Rural Gambia. African Journal of Reproductive Health, 6, 74-83.

The Partnership for Maternal Newborn \& Child Health. (20II). PMNCH Fact Sheet: RMNCH Continuum of care Reproductive, maternal, newborn and child health. Retrieved o5 June 2014, 2014, from http://www.who.int/pmnch/about/continuum_of_care/en/

Tomasoni, L.R., Galli, M., Declich, S., Pietra, V., Croce, F., Pignatelli, S. et al. (20II). Knowledge, attitudes and practice (KAP) regarding newborn feeding modalities in HIV-infected and HIV-uninfected pregnant women in sub-Saharan Africa: a multicentre study. International Health, 3, 56-65.

United Nations Departement of Economic and Social Affairs Population Division: Population Estimates and Projections Section. (2014). World Population prospects: The 2012 revision (January $2014 \mathrm{ed}$.).

Waiswa, P., Kemigisa, M., Kiguli, J., Naikoba, S., Pariyo, G.W. and Peterson, S. (2008). Acceptability of evidence-based neonatal care practices in rural Uganda - implications for programming. BMC Pregnancy and Childbirth, 8, 2I.

Wang, W., Alva, S., Wang, S. and Fort, A. (20II). Levels and Trends in the Use of Maternal Health Services in Developing Countries DHS Comparative Reports No. 26. Calverton, Maryland, USA: ICF Macro.

Wanjira, C., Mwangi, M., Mathenge, E., Mbugua, G. and Nganga, Z. (20II). Delivery Practices and Associated Factors among Mothers Seeking Child Welfare Services in Selected Health Facilities in Nyandarua South District, Kenya. BMC Public Health, 11(360). doi:Io.II86/I47I-2458-II-360. 
Warren, C., Daly, P., Toure, L. and Mongi, P. (2006). Chapter 4, The postnatal care. In: The Partnership for Maternal, Newborn \& Child Health (ed.). Opportunities for Africa's Newborns. Geneva: WHO, 7990.

Mwangi, A., Oweya, E., Kamunya, R. and Koskei, N. (2010). Safeguarding maternal and newborn health: improving the quality of postnatal care in Kenya. International Journal for Quality in Health Care, 22, 24-30.

WHO (1998). Postpartum care of the mother and newborn: a practical guide. Geneva: World Health Organization.

WHO (2010). Packages of Interventions for Family Planning, Safe Abortion Care, Maternal, Newborn and Child Health (pp. 20). Geneva, Switzerland: WHO.

WHO UNICEF, UNFPA and The World Bank. (2010). Trends in maternal mortality: 1990-2008. WHO Press, 55 .

World Health Organisation. (2013). WHO recommendations on postnatal care of the mother and new born. In WHO (Ed.), (pp. 72). Geneva, Switzerland.

World Health Organization: Global Health Observatory Data Repository. Cause-specific mortality and morbidity: Maternal mortality ratio by WHO region. Retrieved January 2014 from http://apps.who.int/gho/data/view.main.I39o?lang=en

Zere, E., Tumusiime, P., Walker, O., Kirigia, J., Mwikisa, C. and Mbeeli, T. (20Io). Inequities in utilization of maternal health interventions in Namibia: implications for progress towards MDG 5 targets. International Journal for Equity in Health, 9(I6). doi: Io.II86/I475-9276-9-I6. 